\title{
Monitoring heavy metals, residual agricultural chemicals and sulfites in traditional herbal decoctions
}

\author{
In-Sil Yu ${ }^{1 *}$, Jeong-Sook Lee ${ }^{1}$, Sung-Dan Kim, Yun-Hee Kim', Hae-Won Park', Hoe-Jin Ryu', Jib-Ho Lee', \\ Jeong-Mi Lee ${ }^{1}$, Kweon Jung ${ }^{1}$, Cheol Na ${ }^{2}$, Jin-Yong Joung ${ }^{3}$ and Chang-Gue Son ${ }^{3^{*}}$ (D)
}

\begin{abstract}
Background: Asian traditional herbal preparations are frequently considered for the contamination with undeclared toxic or hazardous substances. The aim of this study was to determine the toxic heavy metals, pesticides and sulfur dioxide in decoctions that is a common form of final utilization in Korea.

Methods: A total of 155 decoctions composed of multi-ingredient traditional herbs were randomly sampled from Seoul in Korea between 2013 and 2014. For each decoction, the concentrations of four heavy metals (arsenic, cadmium, lead and mercury), 33 pesticides and sulfur dioxide were analyzed using inductively coupled plasma mass spectrometry (ICP-MS), mercury analyzer, gas chromatography/nitrogen phosphorous detector (GC/NPD), gas chromatography/micro electron capture detector (GC/MECD), and Monier-Williams method respectively.

Results: One hundred fifty-two of One hundred fifty-five decoctions (98.1\%) contained one of three heavy metals (96.1\% for As, $97.4 \%$ for $\mathrm{Cd}$, and $90.3 \%$ for $\mathrm{Pb}, 0.0 \%$ for $\mathrm{Hg}$ ). Their average concentrations $(77.0 \pm 79.7 \mathrm{ug} / \mathrm{kg}$ for As, $20.4 \pm 23.7 \mathrm{ug} / \mathrm{kg}$ for $\mathrm{Cd}$, and $68.8 \pm 76.5 \mathrm{ug} / \mathrm{kg}$ for $\mathrm{Pb}$ ) were approximately $20 \%$ of the maximum allowable limits of vegetable or ginseng beverage described in the Korean Food Standard Codex while their 95th percentile concentrations were below than the guideline for them. None of 33 pesticides was detected in 155 decoction samples, and only one sample showed over limit of detection for residual sulfites.

Conclusions: This study support that the contained status of toxic heavy metals, pesticides and sulfur dioxide in herbal decoctions are currently within safe level in Korea, and provide a reference data for the further studies focused on the safety herbal preparations.
\end{abstract}

Keywords: Herbal decoction, Quality control, Contamination, Heavy metals, Pesticides, Sulfur dioxide

\section{Background}

Herbal medicines have been used to manage various diseases and ailments for thousands of years particularly in East Asia, and herbal products became popular worldwide. The global market for herbal products is continuously growing, and reached US $\$ 83$ billion in 2012 [1]. About 40\% of individuals in Korea and China,

\footnotetext{
*Correspondence: yis9729@seoul.go.kr; ckson@dju.ac.kr

${ }^{1}$ Kangbuk Agro-Fishery Products Inspection Center, Seoul Metropolitan Government Research Institute of Public Health and Environment, \# 5 Yangnyeongjungang-ro, Dongdaemun-gu, Seoul 130-864, Republic of Korea ${ }^{3}$ Liver and Immunology Research Center, Daejeon Oriental Hospital of Daejeon University, \# 176-9 Daeheung-ro, Jung-gu, Daejeon 302-724, Republic of Korea

Full list of author information is available at the end of the article
}

and $18 \%$ of adults in the United States adopt herbal remedies to treat illnesses [2-4]. However, with the ever-increasing use of herbal medicines worldwide, many concerns have been raised regarding especially the safety and quality control of medicinal plant materials and herbal products $[5,6]$.

Safety and quality of herbal medicines are affected by many factors, intrinsic factor like species differences and extrinsic factors including environment, collection methods, cultivation, harvest, post-harvest processing, transport, and storage practices [7]. Quality control directly impacts not only the safety of herbal medicinal products also their efficacies [8]. Compared with synthetic drugs, assurance of quality control of herbal 
drugs, determining identity, purity, content, and biological property, are much more complex [9]. In addition, adulteration with undeclared other substances and contamination with undeclared toxic or hazardous substances are most likely to be found in herbal materials or herbal products [10]. The toxic heavy metals, residual pesticides or improper use of sulfites are regarded as potent risk factors in use of herbal medicines because they can be easily contaminated in herbal materials due to soil pollution and process of cultivation, harvesting and storage [11-13].

Those contaminants are known to be harmful in human health under certain levels, and then the allowable limits in medicinal herbs are under strict regulation by various countries including Korea [14]. The medicinal herbs are generally utilized as decoction forms of multiple herbal formulas especially in East Asia countries, which can change the quantities of contaminants in process of decoction [15]. In contrast many studies for quantification of those contaminants in herbal materials, very few information have been conducted for the herbal decoction to date.

This study firstly presents the levels of four toxic heavy metals, 33 pesticides and sulfites in 155 decoctions collected randomly from Seoul in Korea.

\section{Methods}

\section{Collection of decoctions}

One hundred fifty five decoctions (155 different formulae) were randomly collected from 51 oriental clinics (89 formulae), 7 herbal pharmacies (31 formulae) and 10 herbal medicine shops ( 35 formulae) between September 242013 and May 4, 2014 (Additional file 1: Table S1). The decoctions are generally prepared by adding $200 \mathrm{~g}$ of medicinal herbs to $1 \mathrm{~L}$ of water and boiling for $2 \mathrm{~h}$. Each decoction contained approximately $100 \mathrm{ml}$ of herbal solution in plastic bag. This one bag of decoction corresponds to a dose for an adult patient, which an adult generally takes $200 \mathrm{ml}$ (two bags) as daily clinical dose.

\section{Analyses of heavy metals \\ Sample digestion and determination of element concentrations}

Three heavy metals including arsenic (As), cadmium $(\mathrm{Cd})$ and lead $(\mathrm{Pb})$ were analyzed in decoction samples a using Inductively Coupled Plasma Mass Spectrometry (ICP-MS) (Agilent 7500ce, Agilent, Tokyo, Japan). Multi-element Calibration Standard 2A (Agilent, Santa Clara, CA, USA) containing $100 \mathrm{mg} / \mathrm{L}$ of $\mathrm{Pb}, \mathrm{Cd}$ and As were used for external calibration. Working standards were prepared daily in $5 \%$ of $\mathrm{HNO}_{3}(70 \%$, v/v, Dong Woo Fine-Chem Co., Iksan, Korea). Eight standards were prepared at concentrations ranging from 0 to $100 \mathrm{ug} / \mathrm{L}$.
Samples were digested using a microwave digestion system (MARS 5; CEM, Matthews, NC, USA). Before use, the sample vessels were decontaminated in a bath of $10 \%$ of nitric acid, then rinsed with ultrapure water $(18.2 \mathrm{~m} \Omega$ ) (MQ gradient; Millipore, Bedford, MA, USA) and dried in a $40{ }^{\circ} \mathrm{C}$ oven. $2 \mathrm{~g}$ of decoction samples were weighed precisely in digestion vessels and wet-oxidized with $12 \mathrm{~mL}$ ultrapure $\mathrm{HNO}_{3}$ in the microwave digestion system. One randomly selected vessel was filled with reagents only and taken through the entire procedure as a blank. The microwave digestion system was sealed up and heated for over $15 \mathrm{~min}$ at $190^{\circ} \mathrm{C}$ by applying $1200 \mathrm{~W}$, and the sample was digested for $15 \mathrm{~min}$. After cooling at room temperature, sample solutions were quantitatively transferred into $50 \mathrm{~mL}$ polyethylene flasks. The digested samples were then filled with ultrapure water to the final volume before analysis by ICP-MS. The operation parameters of ICP-MS are listed in Table 1.

The analysis of mercury $(\mathrm{Hg})$ was analyzed by mercury analyzer (MA-2, Nippon Instrument Co., Tokyo, Japan) using $50 \mathrm{mg}$ of decoction sample. Additive aluminum oxide (BHT ${ }^{\oplus}$, Nippon Instruments Corp., Tokyo, Japan)

Table 1 ICP-MS operating conditions and data acquisition parameters

\begin{tabular}{ll}
\hline Operation condition & \\
Nebuliser & Quartz concentric (Micromist) $400 \mathrm{\mu L} / \mathrm{min}$ \\
Spray chamber & Scott-type double-pass water cooled \\
Cell geometry & Octopole \\
Sampling cone & Nickel, $1.0 \mathrm{~mm}$ orifice \\
Skimmer cone & Nickel, $0.4 \mathrm{~mm}$ orifice \\
RF power & $1400-1500 \mathrm{~W}$ \\
Reflected power & $<10 \mathrm{~W}$ \\
He mode (collision cell mode) & \\
Plasma gas flow & $15 \mathrm{~L} / \mathrm{min}$ \\
Nebuliser gas flow & $0.95-1.00 \mathrm{~L} / \mathrm{min}$ \\
Auxiliary gas flow & $0.99 \mathrm{~L} / \mathrm{min}$ \\
He gas flow & $3.5 \mathrm{~mL} / \mathrm{min}$ \\
Expansion stage & $2.0 \mathrm{mbar}$ \\
Intermediate stage & $2.0 \times 10^{-4}-3.0 \times 10^{-4} \mathrm{mbar}$ \\
Analyzer stage & $1.0 \times 10^{-4}-2.0 \times 10^{-4} \mathrm{mbar}$ \\
Octopole bias & $-18 \mathrm{~V}$ \\
Quadrupole bias & $-16 \mathrm{~V}$ \\
Acquisition parameters & \\
Mass range & $2-260 \mathrm{a} . \mathrm{m} . \mathrm{u}$ \\
Number of channels & 500 \\
Dwell time & $300 \mathrm{~ms}$ \\
Number of sweeps & 500 \\
Total acquisition time & $14.6400 \mathrm{~s}$ \\
\hline
\end{tabular}


was placed in an analytical boat with sample. And then additive BHT was covered and additive calcium hydroxide and sodium carbonate (MHT $^{\bullet}$, Nippon Instruments Corp., Tokyo, Japan) was filled on the boat. The mercury was decomposed by heating to high temperatures and vaporized, captured, and concentrated on the collector surface made of a multi-porous substance that was coated with gold. And then, it was released into an atomic absorption measuring device and measured at $253.7 \mathrm{~nm}$ by mercury analyzer. Five external working standards of $\mathrm{Hg}$ were prepared in a concentration range from 0 to $20 \mu \mathrm{g} / \mathrm{kg}$ by diluting $\mathrm{Hg}$ standard stock solution $(994 \mathrm{mg} / \mathrm{L}$, Kanto Soka, Japan) with $0.001 \% \mathrm{~L}-$ cysteine solution (98\%, Nacalai Tesque Inc., Kyoto, Japan). The operation parameters of mercury analyzer are listed in Table 2.

\section{Quality assurance}

Several parameters were evaluated for the validation of the analytical method followed, for determination of As, $\mathrm{Cd}, \mathrm{Pb}$ and $\mathrm{Hg}$ in decoctions. The parameters were linearity, precision, accuracy, limit of detection (LOD), and limit of quantification (LOQ). For the linearity, linear regression coefficients ( $\mathrm{r} 2$ ) should be $>0.999$ for $\mathrm{As}, \mathrm{Cd}$, $\mathrm{Pb}$ and $\mathrm{Hg}$ in every analytical batch. The accuracies of the measurements were assessed using NIST 1547 (peach leaves), NIST 1573a (tomato leaves) and Nist 1568b (rice flour) from National Institute of Standards and Technology (Gaithersburg, MD, USA) as Certified Reference Material. The precision of analytical procedure was usually expressed as the variance or the coefficient of variation $(\mathrm{CV})$ of a series of measurements. The precision was evaluated using a relative standard deviation of five repeated determination of one sample [16]. The recovery percentages and percent coefficient of variation $(\mathrm{CV} \%)$ are shown in Table 3 . The capability of the

Table 2 Mercury analyzer operating conditions

\begin{tabular}{ll}
\hline Parameter & Condition \\
\hline Mode selector & Standard: 1, Sample : 2 \\
Heating mode & Two available modes \\
Gas washing bottle & Buffer: $\mathrm{H}_{2} \mathrm{O}=1: 1(\mathrm{v} / \mathrm{v})$ \\
Flow meter & $0.5 \mathrm{~L} / \mathrm{min}$ \\
Sample heating furnace $\mathrm{H} 1$ & Mode $1: 600{ }^{\circ} \mathrm{C}(2 \mathrm{~min})$, Mode 2: \\
& $800{ }^{\circ} \mathrm{C}(4 \mathrm{~min})$ \\
Decomposing furnace $\mathrm{H} 2$ & Heated at $850{ }^{\circ} \mathrm{C}$ \\
Mercury collector $\mathrm{H3}$ & About Heated at $700{ }^{\circ} \mathrm{C}$ \\
Carrier gas & Purified dry air \\
Additive & Standard: unnecessary, Sample: \\
& $\mathrm{B}+\mathrm{S}+\mathrm{B}+\mathrm{M}^{\mathrm{a}}$ \\
\hline
\end{tabular}

${ }^{a} \mathrm{M}$ : Sodium carbonate anhydrous: Calcium hydroxide $=1: 1(\mathrm{v} / \mathrm{v}) ; \mathrm{B}$ : Aluminum oxide anhydrous; S: Sample method was estimated through the determination of the detection limits of every element studied. The limits of detection (LOD) and limits of quantification (LOQ) were calculated with three and ten times the standard deviation of the blank divided by the slope of the analytical curve, respectively [17].

\section{Risk assessment}

According to the recommendations from The Joint FAO/ WHO Expert Committee on Food Additives [18] the risk assessment for contamination of the heavy metals was conducted by comparing the percentage value of provisional tolerable weekly intake (PTWI). PTWI value was converted from the Average Daily Dose (ADD, $\mathrm{mg} / \mathrm{kg} /$ day) which was computed according to Eq. (1).

$$
\mathrm{ADD}=(\mathrm{CH} \times \mathrm{ID} \times \mathrm{EF} \times \mathrm{ED}) /(\mathrm{BW} \times \mathrm{AT})
$$

where ADD is the average daily dose ( $\mathrm{mg} / \mathrm{kg} /$ day), $\mathrm{CH}$ is the concentration of toxic metals $(\mathrm{mg} / \mathrm{kg}$ ), ID is the ingestion dose ( $\mathrm{mL} /$ day), $\mathrm{EF}$ is the exposure frequency (day/year), ED is the exposure duration (60 year), BW is the body weight $(\mathrm{kg})$, and AT is the average life span of Korean people ( 80 years). The exposure calculation was based on the following assumption; the ingestion of a $100 \mathrm{~mL}$ decoction twice a day to a $60 \mathrm{~kg}$ adult for 30 days performed 3 times in a year. Toxic metal concentrations for ingestion were set for two cases, a mean value and a 95th percentile value respectively.

\section{Analysis of residual agricultural chemicals Determination of concentrations of 33 pesticides}

Thirty three pesticides were analyzed using a protocol for multi class pesticide multiresidue methods proposed by ministry of food drug safety (MFDS) in Korean [19]. Gas chromatography/nitrogen phosphorous detector (GC/ NPD, HP6890N, Agilent Technologies, USA) and GC/micro electron capture detector $(\mathrm{GC} / \mu \mathrm{ECD}, \mathrm{HP} 6890 \mathrm{~N}$, Agilent Technologies, USA) were used for analysis of 1 herbicides, 1 acaricides, 18 insecticides and 13 fungicides respectively (Additional file 1: Table S2). A $50 \mathrm{ml}$ of distilled water was added to $20 \mathrm{~g}$ of decoction, and then the diluted decoction was extracted with $100 \mathrm{~mL}$ of acetonitrile using rotary shaker for $1 \mathrm{~h}$. The homogenized decoction was filtered using a qualitative filter paper with $18.5 \mathrm{~cm}$ diameter (Ahlstrom Filtration LLC, Mt. Holly Springs, PA, USA), and then the filtrates were vigorously shaken in a milk bottle containing $10 \mathrm{~g}$ of sodium chloride. A $10 \mathrm{~mL}$ aliquot of the upper layer (acetonitrile layer) was then taken and evaporated to solid dryness in a water bath at $40{ }^{\circ} \mathrm{C}$. The SPE florisil cartridges were used for purification process. The purified eluates were evaporated to solid dryness using a nitrogen evaporator at $40{ }^{\circ} \mathrm{C}$. 
Table 3 LOD, LOQ, precision and recovery for 4 heavy metals analyzed

\begin{tabular}{lllcccc}
\hline Element & $\begin{array}{l}\text { Reference Value } \\
\text { Mean } \pm \text { SD }(\mathrm{mg} / \mathrm{kg})\end{array}$ & Found & $\begin{array}{l}\text { Recovery } \\
(\%)\end{array}$ & $\begin{array}{l}\text { Precision } \\
(\text { CV\%) }\end{array}$ & LOD & LOQ \\
\hline $\mathrm{AS}$ & $0.285 \pm 0.014^{\mathrm{a}}$ & $0.298 \pm 0.007$ & 104.7 & 2.5 & $0.004 \mu \mathrm{mg} / \mathrm{kg}$ & $0.014 \mu \mathrm{gg} / \mathrm{kg}$ \\
$\mathrm{Cd}$ & $1.52 \pm 0.04^{\mathrm{b}}$ & $1.462 \pm 0.005$ & 96.2 & 0.3 & $0.003 \mu \mathrm{gg} / \mathrm{kg}$ & $0.009 \mu \mathrm{\mu g} / \mathrm{kg}$ \\
$\mathrm{Pb}$ & $0.87 \pm 0.03^{\mathrm{c}}$ & $0.703 \pm 0.021$ & 80.9 & 2.9 & $0.079 \mu \mathrm{mg} / \mathrm{kg}$ & $0.264 \mu \mathrm{gg} / \mathrm{kg}$ \\
$\mathrm{Hg}$ & $0.034 \pm 0.004^{\mathrm{b}}$ & $0.031 \pm 0.003$ & 100.0 & 4.7 & $0.017 \mathrm{mg} / \mathrm{kg}$ & $0.057 \mathrm{mg} / \mathrm{kg}$ \\
\hline
\end{tabular}

${ }^{a}$ Rice flour Certified Reference Material (NIST 1568b), ${ }^{b}$ Tomato leaves Certified Reference Material (NIST 1573a), ${ }^{\mathrm{c}}$ Peach leaves Certified Reference Material (NIST 1547), LOD: limits of detection, LOQ: limits of quantification

The dried extracts were redissolved in $2 \mathrm{~mL}$ of acetone-hexane $(2: 8, \mathrm{v} / \mathrm{v})$ and prepared as test solution. Finally, 33 pesticides were analyzed using DB-5 and DB-1701 capillary dual column and detected by GC/NPD, GC/ $/ \mathrm{ECD}$ and GC/MSD. The analytical conditions of the instruments are shown in Table 4.

\section{Quality assurance}

Quantitative analysis was conducted using an external standard (DB-5 capillary column). The linearity of each pesticide was established by plotting a GC response area versus concentration. The calibration curve was obtained by analyzing the pesticides at three different levels. The correlation coefficient (R2) was found to be $\geq 0.9992$. All pesticides presented a linear behavior in the standard concentration range of $0.05-4.00 \mathrm{mg} / \mathrm{kg}$. The limit of quantification (LOQ) was estimated at the lowest concentration of pesticide injected that yielded a signal/noise ratio of three $(\mathrm{S} / \mathrm{N}) \geq 3$ for each pesticide, while the fortification concentration giving an $\mathrm{S} / \mathrm{N} \geq 10$ was considered as the limit of quantification (LOQ). The LOD and LOQ for the test pesticides were in the range of $0.003-0.097 \mathrm{mg} / \mathrm{kg}$ and $0.009-0.293 \mathrm{mg} / \mathrm{kg}$ (Table 5). To assess the accuracy of the presented method, the recovery tests for 33 pesticides were conducted at three different conditions, $0.5 \mathrm{mg} / \mathrm{kg}, 1.0 \mathrm{mg} / \mathrm{kg}$ and $2.0 \mathrm{mg} /$ kg (Additional file 1: Table S3).

\section{Analyses of sulfites}

\section{Determination of sulfites}

Analysis of sulfites was carried out using the MonierWilliams Method [20]. This method measures free sulfite plus reproducible portion of bound sulfites, such as carbonyl addition products, in sample. This method is applicable of determination of $\geq 10$ ppm sulfites in foods. $50 \mathrm{~g}$ of decoction samples were mixed with $100 \mathrm{~mL} \mathrm{5 \%}$ ethanol (99.9\%, v/v, Fisher, Fair Lawn, Japan). Apparatus and water were deoxygenated with $\mathrm{N}_{2}$ flow at $200 \pm$ $10 \mathrm{~mL} / \mathrm{min}$ for $15 \mathrm{~min}$. Prepared test portion was introduced into the three-neck round bottom distillation flask with $400 \mathrm{~mL}$ of water. In the receiving vessel $30 \mathrm{~mL}$ of $\mathrm{H}_{2} \mathrm{O}_{2}$ (30\%, v/v, Junsei, Tokyo, Japan), previously titrated to a yellow end point with $0.01 \mathrm{~N} \mathrm{NaOH}$ (Wako, Osaka, Japan), was placed. $90 \mathrm{~mL} 4 \mathrm{~N} \mathrm{HCl}(35.0 \sim 37.0 \%$, v/v, Wako, Japan) were added to the flask and the distillation was completed in $1 \mathrm{~h} 45 \mathrm{~min}$. In this way, sulphurous anhydride was distilled and converted to sulphuric acid by reaction with of $\mathrm{H}_{2} \mathrm{O}_{2}$. The sulfuric acid was titrated against $0.01 \mathrm{~N} \mathrm{NaOH}$ with methyl red (Acros, New Jersey, USA) as indicator up to a yellow endpoint that persisted for $\geq 20 \mathrm{~s}$.

\section{Quality assurance}

The accuracy and precision of the method as a routine analysis method was estimated through the FAPAS

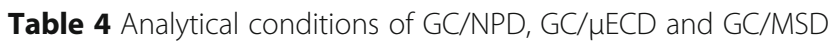

\begin{tabular}{|c|c|c|c|}
\hline Parameter & GC/NPD & $\mathrm{GC} / \mu \mathrm{ECD}$ & GC/MSD \\
\hline Column & $\begin{array}{l}\text { DB-1701 } \\
\text { DB-5 }\end{array}$ & $\begin{array}{l}\text { DB-1701 } \\
\text { DB-5 }\end{array}$ & DB-5 MS \\
\hline Gas flow & $\begin{array}{l}\mathrm{N}_{2}(1.4 \mathrm{~mL} / \mathrm{min}) \\
\text { Air }(60 \mathrm{~mL} / \mathrm{min}) \\
\mathrm{H}_{2}(3.5 \mathrm{~mL} / \mathrm{min})\end{array}$ & N2 (1 mL/min) & $\mathrm{N} 2(1 \mathrm{~mL} / \mathrm{min})$ \\
\hline Injection port temperature & $250^{\circ} \mathrm{C}$ & $230^{\circ} \mathrm{C}$ & $230^{\circ} \mathrm{C}$ \\
\hline Detector temperature & $325^{\circ} \mathrm{C}$ & $280^{\circ} \mathrm{C}$ & \\
\hline Oven temperature & $\begin{array}{l}110^{\circ} \mathrm{C}(1 \mathrm{~min})-15^{\circ} \mathrm{C} / \mathrm{min} \\
200^{\circ} \mathrm{C}(10 \mathrm{~min})-20^{\circ} \mathrm{C} / \mathrm{min} \\
280^{\circ} \mathrm{C}(17 \mathrm{~min})\end{array}$ & $\begin{array}{l}150^{\circ} \mathrm{C}(0.5 \mathrm{~min})-30{ }^{\circ} \mathrm{C} / \mathrm{min} \\
190^{\circ} \mathrm{C}(0.2 \mathrm{~min})-1{ }^{\circ} \mathrm{C} / \mathrm{min} \\
280^{\circ} \mathrm{C}(11 \mathrm{~min})\end{array}$ & $\begin{array}{l}100{ }^{\circ} \mathrm{C}(2 \mathrm{~min})-10{ }^{\circ} \mathrm{C} / \mathrm{min}- \\
320^{\circ} \mathrm{C}(5 \mathrm{~min})\end{array}$ \\
\hline
\end{tabular}

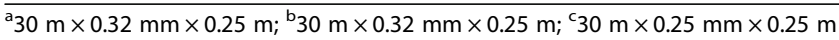


Table $\mathbf{5}$ Linearity of calibration curve, LOD, and LOQ of pesticides

\begin{tabular}{|c|c|c|c|c|}
\hline Pesticides & Regression equation & R2 & 'LOD mg/kg) & ${ }^{\mathrm{d}} \mathrm{LOQ}(\mathrm{mg} / \mathrm{kg})$ \\
\hline$p, p^{\prime}-D D D$ & $y^{b}=374844.59 x^{a}-1258.40$ & 1.0000 & 0.005 & 0.016 \\
\hline$p, p^{\prime}-D D E$ & $y=389791.58 x-2526.36$ & 1.0000 & 0.007 & 0.021 \\
\hline o,p'-DDT & $y=229348.05 x-12990.11$ & 0.9995 & 0.065 & 0.196 \\
\hline p,p'-DDT & $y=254190.24 x-16171.13$ & 0.9996 & 0.045 & 0.136 \\
\hline Bifenthrin & $y=85403.71 x-1585.67$ & 0.9999 & 0.030 & 0.091 \\
\hline Chlorfenapyr & $y=393884.32 x-6112.32$ & 1.0000 & 0.018 & 0.053 \\
\hline Chlorothalonil & $y=475988.22 x-13117.75$ & 0.9999 & 0.031 & 0.094 \\
\hline Cyhalothrin & $y=273407.08 x-11711.69$ & 0.9998 & 0.042 & 0.129 \\
\hline Cypermethrin & $y=146439.59 x-7670.04$ & 0.9995 & 0.060 & 0.181 \\
\hline Dieldrin & $y=474247.23 x-4668.10$ & 1.0000 & 0.007 & 0.020 \\
\hline a-Endosulfan & $y=435974.27 x-2681.56$ & 1.0000 & 0.011 & 0.034 \\
\hline$\beta$-Endosulfan & $y=411096.17 x-3877.12$ & 1.0000 & 0.015 & 0.045 \\
\hline Endosulfan Sulfate & $y=330896.35 x-6530.19$ & 0.9999 & 0.029 & 0.089 \\
\hline Fenarimol & $y=353478.59 x-15843.60$ & 0.9996 & 0.052 & 0.159 \\
\hline Fenpropathrin & $y=102000.65 x-3871.97$ & 0.9998 & 0.042 & 0.127 \\
\hline Hexaconazole & $y=189804.39 x-19048.19$ & 0.9999 & 0.033 & 0.101 \\
\hline Isoprothiolane & $y=102841.63 x-4375.38$ & 0.9996 & 0.051 & 0.154 \\
\hline Kresoxim-methyl & $y=82893.05 x-1863.47$ & 0.9999 & 0.026 & 0.080 \\
\hline Methoxychlor & $y=174878.92 x-5581.06$ & 0.9998 & 0.055 & 0.166 \\
\hline Pendimethalin & $y=95284.06 x-766.05$ & 0.9999 & 0.038 & 0.115 \\
\hline Procymidone & $y=48823.89 x+1832.31$ & 0.9999 & 0.077 & 0.234 \\
\hline Tetradifon & $y=305112.99 x-9039.28$ & 0.9998 & 0.050 & 0.151 \\
\hline Thifluzamide & $y=290010.38 x-5561.51$ & 1.0000 & 0.012 & 0.035 \\
\hline Tolylfluanid & $y=269855.77 x-12090.08$ & 0.9999 & 0.022 & 0.067 \\
\hline Triadimefon & $y=190757.09 x-3508.23$ & 1.0000 & 0.022 & 0.066 \\
\hline Triflumizole & $y=142356.47 x-8256.12$ & 0.9992 & 0.097 & 0.293 \\
\hline Cyprodinil & $y=205.34 x-2.68$ & 1.0000 & 0.045 & 0.138 \\
\hline Iprobenfos & $y=1540.77 x-171.09$ & 0.9999 & 0.074 & 0.225 \\
\hline Napropamide & $y=51.25 x-1.22$ & 1.0000 & 0.036 & 0.109 \\
\hline Tebuconazole & $y=80.37 x-8.08$ & 1.0000 & 0.025 & 0.076 \\
\hline Tebufenpyrad & $y=121.95 x-2.61$ & 1.0000 & 0.044 & 0.132 \\
\hline Triadimenol & $y=91.36 x-5.56$ & 0.9999 & 0.054 & 0.162 \\
\hline Triazophos & $y=1540.77 x-217.58$ & 1.0000 & 0.003 & 0.009 \\
\hline
\end{tabular}

${ }^{a} y=$ peak area, ${ }^{b} x=$ concentration of the respective compounds, ${ }^{C} L O D=3.3 \times \delta / S,{ }^{d} L O Q=10 \times \delta / S(\delta:$ standard deviation, $S:$ the individual slope in calibration curves)

T20100QC (Meat) from Food Analysis Performance Assessment Scheme (Sand Hutton, York, United Kingdom) as Reference Material. The accuracy and precision of sulfites determination by the Monier-Williams Method was calculated as the recovery and $\mathrm{CV} \%$ from the analyses of five replicates as shown in Table 6.

\section{Statistical analysis}

All data are expressed as average value of concentration and standard deviation as well as their distribution
Table 6 Precision and recovery for the Sulfur Dioxide analyzed

\begin{tabular}{lclc}
\hline $\begin{array}{l}\text { Assigned Value } \\
(\mathrm{mg} / \mathrm{kg})\end{array}$ & $\begin{array}{l}\text { Found } \\
\text { Range for }|\mathrm{z}| \leq 2\end{array}$ & $\begin{array}{l}\text { Mean } \pm \text { SD }(\mathrm{mg} / \mathrm{kg}) \\
(\%)\end{array}$ & $\begin{array}{l}\text { Precision } \\
(\mathrm{CV} \%)\end{array}$ \\
\hline $453(375-531)^{\mathrm{a}}$ & $497.6 \pm 3.2$ & 109.8 & 0.6 \\
\hline
\end{tabular}

${ }^{\mathrm{a}}$ Meat Reference Material (FAPAS T20100QC) 
range. Based on the their main clinical indications, the decoction samples were classified into 9 subgroups according to the 10th revision of the International Statistical Classification of Diseases and Related Health Problems after slight modification [21] The differences of average among 9 groups were assessed by one-way analysis of variance followed by a paired Student's $t$-test. Differences with a $P<0.05$ were considered significant.

\section{Results}

\section{Concentration of heavy metals}

One hundred fifty two samples (98.1\%) of 155 decoctions contained at least one of three heavy metals as over detectable levels; As (96.1\%), Cd (97.4\%), and $\mathrm{Pb}$ (90.3\%), but not for $\mathrm{Hg}(0.0 \%)$. Their average concentrations were $77.0 \pm 79.7 \mathrm{ug} / \mathrm{kg}$ (range 0 to 582.4 ) for As, $20.4 \pm 23.7 \mathrm{ug} / \mathrm{kg}$ (range 0 to $219.0 \mathrm{ug} / \mathrm{kg}$ ) for $\mathrm{Cd}$, and $68.8 \pm 76.5 \mathrm{ug} / \mathrm{kg}$ (range 0 to $631.7 \mathrm{ug} / \mathrm{kg}$ ) for $\mathrm{Pb}$ respectively. The 95th percentile concentration was approximately 5 -folds of average value $(304.4 \pm 121.1 \mathrm{ug} / \mathrm{kg}$ for As, $90.1 \pm 56.2 \mathrm{ug} / \mathrm{kg}$ for $\mathrm{Cd}$ and $285.8 \pm 144.1 \mathrm{ug} / \mathrm{kg}$ for $\mathrm{Pb}$ respectively) (Table 7 ).

Among 9 subgroups of samples based on the their clinical main indications by ICD-10, decoctions for psychiatric disorders showed the lowest concentration (approximately 30 to $57 \%$ of whole sample) for $\mathrm{As}, \mathrm{Cd}$ and $\mathrm{Pb}$ while samples for muscular disorders showed the highest value (approximately 150 to $180 \%$ of whole sample). No significant difference was however observed among the groups for their average concentrations (Table 7).

\section{Concentration of pesticides and sulfites}

None of herbal drug sample showed the detectable level for any kinds of 33 pesticides. Regarding the content of residual sulfites, only one decoction sample showed over limit of detection $(10 \mathrm{mg} / \mathrm{kg})$, as a $17.6 \mathrm{mg} / \mathrm{kg}$ (Table 7).

\section{PTWI values of heavy metals}

Average weekly doses ( $\mu \mathrm{g} / \mathrm{kg} /$ week) of total samples were $0.34,0.09$, and 0.03 for $\mathrm{As}, \mathrm{Cd}$ and $\mathrm{Pb}$, which were correspondent to 2.2, 1.3 and $1.2 \%$ of PTWI guided by JECFA. Meanwhile their 95th percentile values were 1.33 (8.9\%), 0.39 (5.6\%), and 1.26 (5.0\%) for As, $\mathrm{Cd}$ and $\mathrm{Pb}$ respectively (Table 8 ). No significant difference was observed among the 9 subgroups (data not shown).

\section{Discussion}

In term of the scientific requirement for safety and efficacy of herbal products, the quality control of herbal resources is priority, and then the assessment of adulteration or contamination with undeclared materials including hazardous substance is an overriding consideration [22]. Therefore, WHO had developed guidelines for assessing quality of herbal medicines, and particularly considered the potential risk of contaminants from the soil or other environmental sources [14]. In this study, we have monitored the residual levels of four heavy metals, 33 pesticides and sulfites in herbal decoctions, which can be contaminated in the process of cultivation, harvesting and storage.

From the measurement of the four residual heavy metals, we found that $98.1 \%$ of samples contained the detectable levels of at least $\mathrm{As}, \mathrm{Cd}$, or $\mathrm{Pb}$ respectively. This detection rate is notably higher than other studies in UAS, which presented the contamination of $\mathrm{As}, \mathrm{Cd}$, $\mathrm{Pb}$ or $\mathrm{Hg}$ in $20.0 \%$ of Ayurvedic herbal products and $19.4 \%$ of Hispanic herbal remedies [23, 24]. This big gap in the prevalence of heavy metal contamination between

Table 7 Concentration of heavy metals, sulfur dioxide and pesticides in herbal decoctions

\begin{tabular}{|c|c|c|c|c|c|c|}
\hline \multirow[t]{2}{*}{ Clarification (Sample N.) } & \multicolumn{6}{|c|}{ Average \pm SD (Range value, ug/kg, but mg/kg for sulfites) } \\
\hline & As & $\mathrm{Cd}$ & $\mathrm{Pb}$ & $\mathrm{Hg}$ & Pesticides & Sulfites \\
\hline Nutritional disorders (41) & $82.9 \pm 97.6(1.3-582.4)$ & $17.8 \pm 12.6(2.9-41.2)$ & $66.5 \pm 100.4(0.0-631.7)$ & $N^{a}$ & ND & 17.6 (1 sample) \\
\hline Respiratory disorders (36) & $78.5 \pm 84.7(0.0-374.4)$ & $25.4 \pm 39.5(0.0-219.0)$ & $75.8 \pm 71.6(0.0-242.8)$ & ND & ND & ND \\
\hline Digestive disorders (22) & $67.3 \pm 67.2(0-106.9)$ & $14.9 \pm 11.9(0-22.1)$ & $67.1 \pm 55.8(0-121.6)$ & ND & ND & ND \\
\hline Genitourinary disorders (12) & $82.6 \pm 85.3(13.5-245.9)$ & $18.2 \pm 22.9(1.7-86.2)$ & $65.7 \pm 78.1(0.5-25.3)$ & ND & ND & ND \\
\hline Muscular disorders (12) & $118.6 \pm 59.6(7.4-229.4)$ & $36.3 \pm 21.4(3.2-93.9)$ & $107.2 \pm 51.0(21.0-04.7)$ & ND & ND & ND \\
\hline Gynecological disorders (10) & $117.1 \pm 74.4(0.0-237.1)$ & $27.6 \pm 14.3(0.0-45.9)$ & $118.7 \pm 95.7(0-308.4)$ & ND & ND & ND \\
\hline Psychiatric disorders (10) & $30.2 \pm 25.7(0.0-91.5)$ & $11.7 \pm 13.1(0.0-39.9)$ & $21.2 \pm 35.2(0.0-119.2)$ & ND & ND & ND \\
\hline Circulatory disorders (6) & $50.9 \pm 34.4(14.6-112.6)$ & $16.6 \pm 16.7(2.9-46.8)$ & $43.5 \pm 28.3(0.0-79.8)$ & ND & ND & ND \\
\hline Skin disorders (6) & $58.9 \pm 42.5(4.0-129.7)$ & $20.0 \pm 12.8(0.4-38.1)$ & $52.8 \pm 27.2(9.7-81.7)$ & ND & ND & 17.6 (1 sample) \\
\hline \multirow[t]{3}{*}{ Total (155) } & $96.1 \%^{b}$ & $97.4 \%$ & $90.3 \%$ & $0 \%$ & $0 \%$ & $0.7 \%$ \\
\hline & $77.0 \pm 79.7$ & $20.4 \pm 23.7$ & $68.8 \pm 76.5$ & - & - & - \\
\hline & $(0.0-582.4)$ & $(0.0-219.0)$ & $54(0.0-631.7)$ & - & - & - \\
\hline 95th percentile & $304.4 \pm 121.1$ & $90.1 \pm 56.2$ & $285.8 \pm 144.1$ & & & \\
\hline
\end{tabular}


Table 8 ADD and PTWI values of heavy metals in herbal decoctions

\begin{tabular}{|c|c|c|c|c|}
\hline Contents & As & $\mathrm{Cd}$ & $\mathrm{Pb}$ & $\mathrm{Hg}$ \\
\hline Provisional tolerable weekly intake (PTWl, $\mu \mathrm{g} / \mathrm{kg} /$ week) $^{\mathrm{a}}$ & 15 & 7 & 25 & 5 \\
\hline Average daily dose (ADD, $\mu \mathrm{g} / \mathrm{kg} /$ day) & 0.05 & 0.01 & 0.04 & 0 \\
\hline ADD for 95th percentile ( $\mu \mathrm{g} / \mathrm{kg} /$ day) & 0.19 & 0.06 & 0.18 & 0 \\
\hline Average weekly dose (AWD, $\mu \mathrm{g} / \mathrm{kg} /$ week) & 0.34 & 0.09 & 0.30 & 0 \\
\hline Ratio to PTWI & $2.2 \%$ & $1.3 \%$ & $1.2 \%$ & $0 \%$ \\
\hline AWD for 95 th percentile ( $\mu \mathrm{g} / \mathrm{kg} /$ week) & 1.33 & 0.39 & 1.25 & 0 \\
\hline Ratio to PTWI & $8.9 \%$ & $5.6 \%$ & $5.0 \%$ & $0 \%$ \\
\hline
\end{tabular}

a[18, 32]

our study and these reports might result from the drastic difference of detectable levels. In general, traditional Indian medicines are known to use commonly the metal-contained herbal drugs [25], and then about 1000 fold higher concentration of heavy metals comparing to our study was observed in above two studies [23, 24]. In our study, the residual $\mathrm{Hg}$ was not detected in any sample; meanwhile the LOD of $\mathrm{Hg}$ was much higher than other three heavy metals.

In case of exceeding intake, heavy metals poisoning can be induced. Above four heavy metals rank among the priority metals that are of public health significance due to their high degree of toxicity, which can cause multiple organ damage, even at lower levels of exposure [25]. The herbal drug-derived poisoning of heavy metals are frequently reported, likely hemolytic anemia by arsenic intoxication [26], congenital lead poisoning [27], and mercury toxicity following herbal preparations [28]. Moreover, $\mathrm{As}, \mathrm{Cd}, \mathrm{Pb}$ and $\mathrm{Hg}$ are carcinogenic toxic metals [29, 30]. Accordingly, their contents in herbal products are regulated by governments. Our results showed that $\mathrm{As}, \mathrm{Cd}$ and $\mathrm{Pb}$ contents were 2.6, 6.7 and $1.4 \%$ of the maximum allowable limits for herbal medicinal preparation $(\mathrm{As}<3 \mathrm{mg} / \mathrm{kg}, \mathrm{Cd}<0.3 \mathrm{mg} / \mathrm{kg}, \mathrm{Pb}<$ $5 \mathrm{mg} / \mathrm{kg}$, and $\mathrm{Hg}<0.2 \mathrm{mg} / \mathrm{kg}$ ) by Korean MFDS [19].

The final utilizing form of medicinal herbs is generally the decoction especially in East Asia countries; however no guide about the heavy metal contamination exists for herbal decoction. When we compare the beverages using vegetable, tea or ginseng $(\mathrm{Cd}<0.1 \mathrm{mg} / \mathrm{kg}$ and $\mathrm{Pb}<$ $0.3 \mathrm{mg} / \mathrm{kg}$ ) described in the Korean Food Standard Codex [19], our data are near to $20 \%$ of the maximum allowable limits for $\mathrm{Cd}$ and $\mathrm{Pb}$ respectively. The concentrations of those heavy metals were very wide, thus we considered the cases of the top ranking samples for heavy metals. The 95th percentile concentration was approximately 4-folds of average value $(0.3 \mathrm{mg} / \mathrm{kg}$ for As, $0.09 \mathrm{mg} / \mathrm{kg}$ for $\mathrm{Cd}$ and $0.3 \mathrm{mg} / \mathrm{kg}$ for $\mathrm{Pb}$ respectively), which is still less than the guideline for above beverages. In addition, because toxic metals are cumulative poisons, the JECFA recommends comparing the percentage value of PTWI for the individual heavy metals [31]. The PTWI values less than $2.2 \%$ for total samples and $8.9 \%$ for 95th percentile respectively. This result would indicate that the herbal decoctions generally contain the safe range of heavy metals, regarding $\mathrm{As}, \mathrm{Cd}, \mathrm{Pb}$, and especially $\mathrm{Hg}$. We herein adapted PTWI value of As $(15 \mu \mathrm{g} / \mathrm{kg} /$ week $)$. In fact, JECFA however withdrew this PTWI value in 2010 because it was believed to be inappropriate [32]. High levels of toxic metals can sometimes occur in Chinese or Indian herbal medicines when they are used as active ingredients [33], while those cases were absent in our study.

On the other hand, the contamination with residual pesticides or sulfites in herbal remedies is another consideration. The major source of above toxic metal in herbal preparation is the environmental contamination including the soil, water and air [34], while contaminations of the residual pesticides result from mainly in the process of cultivation or harvesting [35]. Although the today's proper use of pesticides is safe and can improve the yield and quality of the agricultural products, there are many concerns about the potential risks associated with pesticide use [36]. Therefore, likely many countries Korean government have restricted the usage of these pesticides establishing tolerances or maximum residue limits (MRLs) in herbal materials [37]. In our study no residual pesticide was detected in 155 decoction samples. In addition, our data revealed that only one sample (decoction of Bojungikkitang, 补中益气汤) contained the detectable level of sulfites $(\geq 10 \mathrm{mg} / \mathrm{kg})$. Sulfites are used as food preservative and can naturally occur in some foods [38], however intake of excess sulfites has been reported to induce a various adverse effects including dermatitis, hypotension, diarrhoea or asthmatic reactions, in especially sensitive individuals [39, 40]. Codex Alimentarius Commission (CAC) recommended that products with sulfites $\geq 10 \mathrm{mg} / \mathrm{kg}$ should always be declared [41], and Korean movement has regulated it with the maximum residue limits (MRLs) of sulfites as $30 \mathrm{mg} / \mathrm{kg}$ in medicinal herbs since 2009 [37]. Bojungikkitang (补中益气汤) is a typical formula supporting the $Q i$ 
of digestive track, which composed of 8 medicinal herbs (Astragali membranaceus Bunge, Panax ginseng C.A. Meyer, Atractylodes japonica Koidzumi, Glycyrrhiza uralensis Fischer, Angelica gigas Nakai, Citrus unshiu Markovich, Cimicifuga heracleifolia Komarov and Bupleurum falcatum Linne) The exact reason for the high level of sulfites $(17.6 \mathrm{mg} / \mathrm{kg})$ in the decoction was unknown.

The quantity of contaminants can be changed in manufacturing process for final products. A study presented the significantly low transfer rates of toxic metals $(10.5 \%$ for As, $4.1 \%$ for $\mathrm{Cd}, 4.3 \%$ for $\mathrm{Pb}$, and $2.7 \%$ for $\mathrm{Hg}$ ) after decoction process of herbal formulae [42]. One study reported a $5.3 \%$ detection rate of residual pesticides and $0.9 \%$ excess MRLs rate among 1565 medicinal herbs [43], and another study presented the $12.5 \%$ excess MRLs rate among136 medicinal herbals [44] in Korea. These data are notably different with our results in current study. One study showed that the boiling process reduces the contamination levels of unwanted contents including heavy metals [45], which is able to explain our finding.

\section{Conclusions}

Taken together, our study presents the current status of herbal decoctions regarding the contamination with heavy metals, pesticides and sulfites, which are in the safe range in Korea. This data would provide a reference to the research field of herbal preparation.

\section{Additional file}

Additional file 1: Table S1. List of 155 herbal formulae and their main compositions. Table S2. Pesticides analyzed in herbal decoctions. Table S3. Recovery for 33 pesticides at three concentration levels. (DOC $231 \mathrm{~kb}$ )

\section{Abbreviations}

ADD: Average daily dose; AWD: Average weekly dose; CAC: Codex Alimentarius Commission; CV\%: Percent coefficient of variation; CV: Coefficient of variation; GC/NPD: Gas chromatography/nitrogen

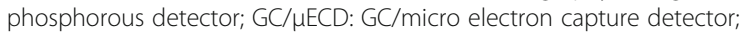
LOD: Limit of detection; LOQ: Limit of quantification; MRLs: Maximum residue limits; ND: Not detected in any sample over detectable level; PTWI: Provisional tolerable weekly intake; R2: Correlation coefficient; S/ $\mathrm{N}$ : Signal/noise ratio of three

\section{Acknowledgements}

Authors thank Seoul Korean Medicine Association, Association of Seoul Oriental Pharmacy and Seoul Oriental Drug Association for their providing the decoction samples. This study was supported by Oriental Medicine Research and Development Project (HI15C-0112), Seoul Metropolitan Government Research Institute of Public Health and Environment, South Korea.

\section{Funding}

Not applicable.

\section{Availability of data and materials}

The dataset supporting the conclusions of this article is included within the article and its additional file.

\section{Authors' contributions}

$J \mathrm{~S}, \mathrm{SD}, \mathrm{YH}$, and HW designed the study and performed the data analyses. HJ, $\mathrm{JH}, \mathrm{JM}$ and $\mathrm{K}$ conducted the data gathering, set up the database. C, JY carried out the data obtained and drafted this paper. IS and CG mainly participated in the design and conduction of the study. All authors read and approved the final manuscript.

\section{Competing interests}

The authors declare that they have no competing interests.

\section{Consent for publication}

Not applicable.

\section{Ethics approval and consent to participate}

Not applicable.

\section{Author details}

${ }^{1}$ Kangbuk Agro-Fishery Products Inspection Center, Seoul Metropolitan Government Research Institute of Public Health and Environment, \# 5 Yangnyeongjungang-ro, Dongdaemun-gu, Seoul 130-864, Republic of Korea. ${ }^{2}$ Seoul Korean Medical Association, \# 420 Kosanja-ro, Dongdaemun-gu, Seoul 130-817, Republic of Korea. ${ }^{3}$ Liver and Immunology Research Center, Daejeon Oriental Hospital of Daejeon University, \# 176-9 Daeheung-ro, Jung-gu, Daejeon 302-724, Republic of Korea.

Received: 21 May 2016 Accepted: 22 February 2017

Published online: 14 March 2017

References

1. WHO. WHO traditional medicine strategy. 2013. p. 2014-23.

2. Yoo TW, Kim Bl, Kim JB, et al. The survey for the actual condition of drug medication and development of health care cost associated with toxic liver injury in Korea: a multicenter study for the detection and the development of nationwide reporting system of toxic liver injury. Korean J Hepatol. 2007; 13(1):34-43.

3. $\mathrm{Xu}$ J, Yang Y. Traditional Chinese medicine in the Chinese health care system. Health Policy. 2009;90(2-3):133-9.

4. Barnes PM, Bloom B, Nahin RL. Complementary and alternative medicine use among adults and children: United States, 2007. Natl Health Stat Report. 2008;12:1-23.

5. Jeong TY, Park BK, Cho JH, et al. A prospective study on the safety of herbal medicines, used alone or with conventional medicines. J Ethnopharmacol. 2012;143(3):884-8.

6. Street RA, Stirk WA, Van Staden J. South African traditional medicinal plant trade-Challenges in regulating quality, safety and efficacy. J Ethnopharmacol. 2008;119(3):705-10.

7. Fong $\mathrm{HH}$. Integration of herbal medicine into modern medical practices: issues and prospects. Integr Cancer Ther. 2002;1(3):287-93.

8. Li SP, Zhao J, Yang B. Strategies for quality control of Chinese medicines. J Pharm Biomed Anal. 2011;55(4):802-9.

9. Sahoo N, Manchikanti P, Dey S. Herbal drugs: standards and regulation. Fitoterapia. 2010:81(6):462-71.

10. Zhang J, Wider B, Shang H, Li X, Ernst E. Quality of herbal medicines: challenges and solutions. Complement Ther Med. 2012;20(1-2):100-6.

11. Sarma H, Deka S, Deka H, Saikia RR. Accumulation of heavy metals in selected medicinal plants. Rev Environ Contam Toxicol. 2011;214:63-86.

12. Oh $\mathrm{CH}$. Monitoring of residual pesticides in herbal drug materials of Korea and China. Bull Environ Contam Toxicol. 2009;82(5):639-43.

13. Kan WL, Ma B, Lin G. Sulfur fumigation processing of traditional chinese medicinal herbs: beneficial or detrimental? Front Pharmacol. 2011;2(84):1-7.

14. WHO. WHO guidelines for assessing quality of herbal medicines with reference to contaminants and residues. 2007. p. 1-35.

15. Seo CS, Huang DS, Lee JK, et al. Concentration of heavy metals, residual pesticides and sulfur dioxide before/after a decoction. J Korean Oriental Med. 2009;30(4):108-17.

16. Chudzinska M, Baralkiewicz D. Application of ICP-MS method of determination of 15 elements in honey with chemometric approach for the verification of their authenticity. Food Chem Toxicol. 2011;49(11):2741-9.

17. Thompson M, Ellison SLR, Wood R. Harmonized guidelines for single laboratory validation of methods of analysis (IUPAC Technical Report). Pure Appl Chem. 2002;74:835-55. 
18. JECFA. Report of the Joint FAO/WHO consultation of food consumption and exposure assessment of chemicals. Geneva: WHO Press; 1997. p. 10-4.

19. MFDS. Notification for Food Standards and Specifications (Number 2015-78). $\mathrm{http} / / / \mathrm{www} . \mathrm{mfds} . \mathrm{go} . \mathrm{kr} / \mathrm{index} . \mathrm{do}$ ?mid $=686 \&$ page $\mathrm{No}=4 \& \mathrm{seq}=10086 \& \mathrm{cmd}=\mathrm{v}$. Accessed 15 May 2016.

20. Association of Analytical Communities. AOAC Official Methods of Analysis. chapter 47. In: Monier-Williams AOAC official method (optimized method) 990.28. Gaithersburg: AOAC International; 2000. p. 29-30.

21. WHO. International Statistical Classification of Diseases and Related Health Problems -10 (ICD-10). http://apps.who.int/classifications/icd10/browse/ 2016/en. Accessed 15 May 2016.

22. Posadzki P, Watson L, Ernst E. Contamination and adulteration of herbal medicinal products (HMPs): an overview of systematic reviews. Eur J Clin Pharmacol. 2013;69(3):295-307.

23. Saper RB, Kales SN, Paquin J, et al. Heavy metal content of ayurvedic herbal medicine products. JAMA. 2004;292(23):2868-73.

24. Levine M, Mihalic J, Ruha AM, French RN, Brooks DE. Heavy metal contaminants in yerberia shop products. J Med Toxicol. 2013;9(1):21-4.

25. Gogtay NJ, Bhatt HA, Dalvi SS, Kshirsagar NA. The use and safety of nonallopathic Indian medicines. Drug Saf. 2002;25(14):1005-19.

26. Lee JJ, Kim YK, Cho SH, et al. Hemolytic anemia as a sequel of arsenic intoxication following long-term ingestion of traditional Chinese medicine. J Korean Med Sci. 2004;19(1):127-9.

27. Tait PA, Vora A, James S, Fitzgerald DJ, Pester BA. Severe congenital lead poisoning in a preterm infant due to an herbal remedy. Med J Aust. 2002; 177(4):193-5.

28. Soumya L, Pandalai, Brent W. Morgan case files of the Emory university medical toxicology fellowship: inhalational mercury toxicity from a traditional Vietnamese product. J Med Toxicol. 2011;7(4):295-305.

29. IARC. IARC monographs on the evaluation of carcinogenic risks to humans. http://monographs.iarc.fr/ENG/Classification/index.php. Accessed 15 May 2016.

30. Sohn J, Lee C. The risk assessment of hazard chemical in environment. J Korean Soc Environ Eng. 2007;29:477-88.

31. Kim JA, Lee SH, Choi SH, et al. Heavy metal risk management: case analysis. Toxicol Res. 2012;28(3):143-9.

32. JECFA. Short information documents for decision makers. http://www.who. int/ipcs/assessment/public health/arsenic/en/. Accessed 15 May 2016.

33. Ernst E. Toxic heavy metals and undeclared drugs in Asian herbal medicines. Trends Pharmacol Sci. 2002;23(3):136-9.

34. Ezeabara CA, Okanume OE, Emeka AN, Okeke CU, Mbaekwe El. Heavy metal contamination of herbal drugs: implication for human health-a review. Int J Trop Dis Health. 2014;4(10):1044-58.

35. Oh CH. Multi residual pesticide monitoring in commercial herbal crude drug materials in South Korea. Bull Environ Contam Toxicol. 2007;78(5):314-8.

36. Zhou P, Zhao Y, Li J, et al. Dietary exposure to persistent organochlorine pesticides in 2007 Chinese total diet study. Environ Int. 2012;42:152-9.

37. MFDS. Notification for Food Standards and Specifications (Number 200935). http://www.mfds.go.kr/index.do?mid=686\&seq=2435\&cmd=v. Accessed 15 May 2016.

38. Mischek D, Krapfenbauer-Cermak C. Exposure assessment of food preservatives (sulphites, benzoic and sorbic acid) in Austria. Food Addit Contam. 2012;29(3):371-82

39. Zhang JB, Zhang $\mathrm{H}$, Wang $\mathrm{HL}$, et al. Risk analysis of sulfites used as food additives in China. Biomed Environ Sci. 2014;27(2):147-54.

40. Vally H, Misso NL, Madan V. Clinical effects of sulphite additives. Clin Exp Allergy. 2009:39(11):1643-51.

41. FAO/WHO. Codex general standard for the Labelling of Prepackaged Foods. CODEX STAN 1-1985. 2008.

42. Kim DG, Lee SD, Yu IS, Jung K, Park SK. Transfer rates of toxic metals during decoction preparation from hebal medicines and safety evaluation of the final decoction products. Food Sci Biotechnol. 2015:24(2):757-63.

43. Choi YH, Park SK, Kim OH, et al. Pesticide residues monitoring of medicinal herbs in Seoul. Korean J Pesticide Sci. 2011;15(4):335-49.

44. Lee AR, Jang $\mathrm{S}, \mathrm{Kim} \mathrm{TH}$, et al. Monitoring of residual sulfur dioxide in herbal medicines distributed at domestic. Korean J Medicinal Crop Sci. 2013;21(2): 124-9.

45. Ting A, Chow $Y$, Tan W. Microbial and heavy metal contamination in commonly consumed traditional Chinese herbal medicines. J Tradit Chin Med. 2013;33(1):119-24.

\section{Submit your next manuscript to BioMed Central and we will help you at every step:}

- We accept pre-submission inquiries

- Our selector tool helps you to find the most relevant journal

- We provide round the clock customer support

- Convenient online submission

- Thorough peer review

- Inclusion in PubMed and all major indexing services

- Maximum visibility for your research

Submit your manuscript at www.biomedcentral.com/submit

) Biomed Central 